\title{
Antiquity revisited: Challenges and opportunities in the creation of the new Greek history curriculum
}

\author{
Kostas Kasvikis* - University of Western Macedonia, Greece \\ Georgia Kouseri - Ministry of Education, Greece
}

\begin{abstract}
This paper presents and discusses the rationale behind the curriculum covering ancient Greek history, a topic that is taught twice during the course of Greek compulsory education (covering 6-15 year olds). The undertaking to develop a new history curriculum set the framework for a reconsideration of themes and approaches to the teaching of antiquity, based on changes to the scope, aims, teaching topics, methodological approaches and assessments introduced. The approved new history curriculum attempts to elevate the status of prehistory relative to other historical periods, so as to strike a balance between local, national and global history, highlighting the common origin and evolution of modern humans. It introduces archaeology, material culture and museums as structural tools for research into and understanding of antiquity by students. It also focuses on social and cultural history, and reassesses dominant historiographical views of the ancient world. Additionally, a methodological framework that encourages students to create their own accounts and interpretations of the ancient past is recommended, by proposing activities that support historical enquiry and the development of key historical concepts.
\end{abstract}

Keywords: Greek antiquity; archaeology; history curriculum - Greece; history education; historical understanding

\section{Introduction}

On 17 June 2018, the governments of Greece and the former Yugoslav Republic of Macedonia reached an agreement over the name, identity, history and symbols of the northernmost - and in a sense, for the Greeks, nameless - country, striving to solve a problem created and fed by the competing nationalism in both countries during the early 1990s (Danforth, 1995). The written agreement not only settles the issue of the name of the new country ('North Macedonia'), but, most importantly, also envisages and ensures clearly the exclusive Greek ownership of the history and heritage of ancient Macedonia. Nevertheless, in a strange and contradictory fashion, the strong protests by conservative, nationalist and fascist elements of Greek society, and their political wings, have continuously concentrated on the betrayal of Greek ancient history. This has been articulated through slogans such as 'There is only one Macedonia and it is Greek', which seems to negate the history of Macedonia of any other period (Kotsakis, 1998). This is one of the most recent and obvious examples of the significance of antiquity in Greek identity politics, in this case with regard to the history and culture of ancient Macedonia (see, for example, Tziovas, 2014b: 22). These 
arguments, formulated by the detractors of the agreement, also portray a stereotypical perception and understanding of ancient history, if not an ignorance of it altogether. Furthermore, it is also revealing of the shortcomings of the teaching of ancient history in Greek schools.

\section{Teaching antiquity in Greece}

The teaching of ancient history in Greece is defined by several factors. These include the rationale, direction and content selection for the history curriculum, as well as the relevant textbooks in use, along with the teaching methodologies favoured by the centrally regulated and quite conservative Greek education system. They also include aspects such as the perception of teachers and their attitudes towards the ancient past in the context of the aforementioned views of antiquity by parts of Greek society. The latter is the outcome of a broader perception constructed during the nineteenth century, when antiquity was proclaimed to be the cornerstone of national history, and the classical past was effectively used to define modern Greek national identity (Kotsakis, 1991). In this respect, both historiography and archaeology developed as the national sciences par excellence, and contributed to the documentation of this direct link between the modern Greek state and its glamorous ancient past.

Thus, from the late nineteenth century, the historical continuity of the nation from ancient times to the present was established, with antiquity being fundamental in defining an unbroken Greek identity (Herzfeld, 1982; Hamilakis, 2007: 57-123; Liakos, 2001; Skopetea, 1988: 190-204). As early as the foundation of the Greek state, education incorporated and highlighted selected elements of antiquity, beginning with the ancient Greek language, in order to foster national consciousness among the new generations. School history education very soon adopted and reproduced the historical norms and interpretations that had been used to further Greek national identity, based in particular on the idealization and admiration of the glorious epochs of Homer, Leonidas and Socrates (Avdela, 1998: 18-21; Koulouri, 1988). This instrumentalization of antiquity remained active and effective throughout the twentieth century (see chapters in Damaskos and Plantzos, 2008; Tziovas, 2014a). It is evident, for example, in the quest for the return of the Parthenon marbles from the British Museum and in the demand for the exclusive use of the name 'Macedonia' and the ownership of ancient Macedonian heritage by Greece. In addition, the values of the ancient Greek past remain clearly visible in the history curricula and textbooks used (Kasvikis, 2004).

Today, due to the spiral structure used in the Greek curriculum, ancient history is taught twice during compulsory education (covering 6-15 year olds): the first time during the fourth grade of primary education (9-10 years old), and the second time during the first grade of the gymnasium (lower secondary education, 12-13 years old). In addition, it is also taught during the first grade of the lyceum (upper secondary education, 15-16 years old). Primary and secondary school teachers, although having different training and qualifications (Repoussi, 2011:357-60), often rely entirely on history textbooks as their only teaching and source material, resulting in a standardization of teaching practices in the classroom (Avdela, 2000: 240, 244; Kokkinos et al., 2005: 102 3; Mavroskoufis, 1997: 81; Repoussi, 2011: 348-9). In educational terms, the teaching of antiquity relies on the tradition of memorization, and on the wider conceptualization of history as a fact-based subject, rather than one with which students actively engage (Avdela, 2000: 243; Kouseri, 2015: 439). It is based on large numbers of objective accounts of the past, which students are obliged to remember and regurgitate, but not to critically assess. In this context, historical enquiry and engagement with primary or 
secondary sources of evidence are not favoured, or, at least in the secondary education context, are restricted to a simple affirmation of the official narrative provided by the textbooks (Avdela, 2000: 246).

A linear narrative employing the typical system of style-based periodization (for example, Geometric, Archaic and Classical periods) has determined the content arrangement of antiquity in the history curricula and textbooks since the nineteenth century. In addition, the dominance of political and military history defines the structure of the textbooks, along with the artistic and intellectual achievements of the Classical period, effectively supporting and endorsing the myth of national superiority (see also Hamilakis, 2003: 56). A closer examination of history textbooks, and empirical research about classroom practices, reveals a typically ethnocentric perspective of history and the symbolic value of Greek antiquity, mostly Classical. This emerges explicitly or implicitly from the textbooks, as well as through classroom activities and the discourse of the teachers themselves, all of which serve to underline the singularity of Greece's ancient past (Hamilakis, 2003; Kasvikis, 2004; papers in Fragkoudaki and Dragona, 1997).

Despite the recent reorientation of textbook content towards a more neutral presentation of ancient history, a person-centred approach and content based on facts is still the norm, with an overemphasis on important historical figures, events and famous ancient conflicts, such as the Persian and Peloponnesian wars and Alexander's expedition into Asia. These revised textbooks still attempt to avoid discussing dark and negative historical incidents in order to build a coherent but idealized picture of the past, which supports the notion of historical continuity with antiquity (Fragkoudaki, 1997; Hamilakis, 2003). In this regard, the relative stability in the practice of teaching ancient history, despite the educational initiatives introduced by progressive governments over the course of the twentieth century, can be explained through the sacred and legitimizing role played by antiquity in Greek national identity and collective memory (Hamilakis, 2007; Kyrtatas, 2002; Plantzos, 2016). It is telling that the textbook for the first grade of secondary education (Tsaktsiras and Tiverios, 1983) was handed out every year from 1983 until 2000, with no heed paid to the two revisions to the history curriculum that took place in 1985 and 1997 (Papakosta, 2017).

The result of this ideological and practical framework when applied to the teaching of history is the marginalization of early prehistory in the curricula and textbooks, mostly the Palaeolithic and Neolithic, along with that of the Near East and Egypt, all considered peripheral to the role of cementing Greek national identity. On the other hand, the Minoan and Mycenaean cultures of the second millennium BC are widely included in the syllabus to emphatically serve the nationalist normative narrative. More recently, increased emphasis has been placed on both periods in primary school textbooks, promoting a concept of national historical continuity that extends further back beyond Greek antiquity of the first millennium BC (Kasvikis, 2012). In many cases, a quasi-historical and semi-mythological approach is adopted, outdated facts are employed, and stereotypical views are reproduced in the textbook narratives about prehistory (Hamilakis, 2003; Kasvikis, 2004; Kasvikis et al., 2007, 130-3). In addition, it is known that on occasion it has been suggested to secondary school teachers that they teach prehistory briefly, or omit it, in order to save time for the teaching of Classical antiquity.

In parallel with the treatment of prehistory in textbooks and curricula in general, archaeology as a narrative, as well as a source of evidence about the past, has played only a minor role in the development of historical understanding among students. This is quite contradictory, considering the abundant presence of archaeological information in primary textbooks (Kasvikis, 2004) and the important part played by archaeology 
in Greek national consciousness (Hamilakis, 2007; papers in Damaskos and Plantzos, 2008; Plantzos, 2016). It is also surprising, given that archaeology was proclaimed as a national science in the nineteenth century, even before historiography (Kotsakis, 1991; Skopetea, 1988). In practice, though, archaeological information is mostly confined to the presentation of material culture from antiquity in terms of artistic attributes, with an emphasis on the detailed presentation of the Acropolis of Athens, which constitutes both a national emblem of modern Greek identity (Yalouri, 2001) and a source of national pride for students (Kasvikis, 2004). As Papakosta (2017) demonstrates in her analysis of textbooks on ancient history from the primary and secondary school systems during the period 1952 to 2010, older books tend to utilize archaeology for the presentation of arts and fine arts, apart from those chapters dealing with prehistory, where history and archaeology are combined. In the more recent textbooks, the past is presented in chronological order, using the general categorizations of antiquity based on art history; material culture serves as the visual affirmation of the veracity of the historical narrative presented.

\section{A new history curriculum for Greek compulsory education}

A survey of the limited amount of research on Greek history curricula (Avdela, 1998: 18-36; Koulouri, 1988; Mavroskoufis, 1997) reveals the ideological and ethnocentric orientation of the primary and secondary history syllabuses from the late nineteenth and twentieth centuries. Subject matter and knowledge that reaffirm the historical continuity of the nation are a constant priority of the curricula, in order to shape attitudes and cultivate national consciousness and, more recently, democratic citizenship. Only since the 1980s, and mostly in the history curriculum of 2003 (part of the broader Cross-Thematic Curriculum Framework for Compulsory Education by the Ministry of Education - Pedagogical Institute (2003)), have teaching methods incorporating problem solving and historical enquiry been introduced, in parallel with more traditional content knowledge approaches. Nevertheless, the attempts of the 2003 history curriculum to introduce historical thinking, and an understanding of the nature of history, are still to some extent being rendered invalid by inherent structural elements of the curriculum that promote content-oriented knowledge and the traditional aims of education (Repoussi, 2011: 368). For this reason, history education in Greece is apparently falling behind that of many other countries, particularly in terms of curricular developments in content, goals and teaching approaches.

In 2017, the Institute of Educational Policy commissioned a team of academics, teachers, educators and school counsellors specializing in history education to design a new curriculum for compulsory education. The initiative set out to revise the history curriculum, although it was not part of a broader reform of the educational system. Rather, it represented a somewhat fragmented attempt by the left-oriented government of Syriza, Greece's leading political party, to emphasize the importance of history education and to distance themselves from previous conservative and unsophisticated approaches to the subject. The new curriculum follows current international trends in history education and, in particular, the disciplinary approach. Similar approaches to the history curriculum have been attempted in other countries, for example in Cyprus in 2010 (http://archeia.moec.gov.cy/mc/2/istoria.pdf) and in England, where there have been five curricula since the national curriculum was introduced in 1989 - its latest incarnation was in 2013 (DfE, 2013). The curriculum in Cyprus focuses on a small and sufficient body of knowledge, and the cultivation of skills and values, as well as on 
the adoption of attitudes and the demonstration of behaviours that characterize the modern democratic citizen. The curriculum in England is structured along three axes, content, concepts and aims, and there has been a significant amount of discussion regarding the efficacy of such a structure (Burn, 2015, 2016; Chapman et al., 2018: 3-5).

The new Greek curriculum sets out to synchronize history education in Greece with developments in research in the field worldwide, with the aim of improving the way in which history is taught in the Greek primary and secondary school systems. Without ignoring content knowledge, it focuses on the process of history learning, and sets out to develop the cognitive, emotional and psychomotor skills of students. Moreover, it also provides teachers with the flexibility to be able to adapt their teaching approaches to the characteristics of their students, while at the same time improving qualitative assessment methods for both students and teaching procedures. (For the theoretical framework of the new history curriculum, see Voglis et al., 2018.)

In order to be effective in educational terms, the new curriculum strikes a balance between content knowledge and process knowledge, and attempts to challenge the dominant role of school textbooks, while at the same time promoting a more decisive and multifaceted role for teachers. The general aims of history teaching according to the approved new curriculum are as follows: to enable students to formulate genetic historical consciousness, to develop historical thinking, to promote their sense of democratic citizenship and humanistic values, and to build a pluralistic and tolerant national identity (Lee and Ashby, 2000; Barton and Levstik, 2004; Lee, 2005a, 2005b; Rüsen, 2004; Seixas, 2010; Seixas and Morton, 2013; Lévesque, 2008; Chapman, 2015, 2017).

The prescriptions, requirements and guidelines for fulfilling these aims place historical thinking at the core of the teaching and learning process (declarative, procedural and conceptual knowledge), and suggest that history teaching ought to combine thematic and chronological approaches, while at the same time developing first- and second-order concepts and fostering multi-perspectivity and historical empathy, however defined. Other aims include: more emphasis on concepts of time and periodization; the development of historical methodology and improvement of the understanding of how interpretations are formulated based on evidence; the introduction of significance, agency and causality in the process of understanding history; and the engagement of students in activities that support active and experiential learning, utilizing drama, information and communication technologies (ICT), role play, debates, simulations and historical enquiry.

The historical content was revised on the basis of integration of the syllabuses of Greek compulsory education, and a Brunerian spiral curriculum was proposed that creatively combines the chronological and thematic approaches through revisiting syntactic and substantive concepts, themes and content. Through this method, the primacy of conventional political and military history is challenged, and the fields of social, economic and cultural history, along with the history of ideas and institutions, and the history of everyday life, emerge. In addition, new forms of historical research and education that encourage a more experiential and interdisciplinary understanding of the past are introduced. These include new areas of investigation, including family history, oral history, local history, museum education and micro-history.

It is proposed that this new rationale be implemented in practice through two types of teaching material for each grade. The first is the typical textbook, which is the dominant teaching medium in Greece, but now enriched with historical overviews of periods and topics, and multi-modal teaching material and documents that include conflicting sources, images, historical timelines, maps, glossaries, diagrams and 
tables. The second type of teaching material will include thematic teaching packs (thematic dossiers), with which to encourage students to carry out their own research, so deepening their understanding of specific historical topics. The thematic dossiers will include research questions, historical information, activities, multi-modal sources, methodological guidelines and didactic examples, websites and bibliographies. For each grade, teachers will have time for four thematic teaching packs. These will be selected on the basis of a number of options, and will provide teachers with the opportunity to pursue their own teaching paths.

\section{A teaching framework for antiquity: Innovations in the new curriculum}

In this section, we focus on three main innovations of the new history curriculum, particularly in relation to the teaching of antiquity. First, the status of prehistory is upgraded in relation to other historical periods, allowing students to gain a better understanding of the common origin and evolution of modern humans (Homo sapiens). Second, archaeology, museums and material culture are more effectively utilized as research tools, allowing students to gain a better understanding of both prehistory and ancient history. Third, there is a shift towards social and cultural history, and a critical and dispassionate renegotiation of prevalent historiographical approaches to the ancient world.

The new history curriculum of the fourth-grade primary and first-grade lower secondary systems represents an attempt to strike a balance between local history, national history and global connections through the use of prehistory. Content related to prehistory is pushed to the foreground compared with previous curricula, enabling students to gain a better understanding not only of the common origin and evolution of the human species, but also to provide them with the knowledge to counter the many existing stereotypical public perceptions of the period. As already discussed, until quite recently the presentation of prehistoric periods in textbooks and curricula has been partial and inchoate. This was due to the restrictions imposed by the use of a single school textbook as the sole teaching resource, with prehistory, and especially the Palaeolithic, partially or completely excluded as a topic of study (Kasvikis et al., 2007: 131-3; Kasvikis, 2012), in contrast to the situation in many other parts of the world (Stone and McKenzie, 1990).

The new syllabus includes the prehistoric period in equal measure with the periods of antiquity that had until recently enjoyed primacy within the curriculum. Emphasis is placed on the extensive periods of prehistory and Greek prehistory in defining arrangements, sequences and changes over time. The aim is to make students aware of the whole range of past human activity and from a global perspective, as well as to give them an appreciation of the common human conditions that govern history, from the first appearance of humans to the complex societies of late prehistory and of Greek and Roman antiquity. At the level of first-order, substantive concepts, students will examine the basic features and key concepts of the prehistoric period (hunting and gathering, mobility, nomadism, tool technology, farming, social hierarchy) by exploring a variety of sources. Second-order disciplinary, syntactic concepts will be investigated through the use of worksheets presenting varying and conflicting views (from archaeologists and anthropologists) on the origin, behaviour, appearance and evolution of the human species. For example, in the first grade of secondary school, one of the activities proposed is to critically observe and comment on pictorial representation of men, women and children in school textbooks, popular literature, 
scientific publications, comics, films and cartoons (for instance, The Flintstones), and to discuss the validity or otherwise of their stereotypical depictions.

The choice of thematic teaching packs for prehistory favours the exploration of events and processes over long periods, so that students can acquire a deeper understanding of wider historical contexts. Current research demonstrates the need for cultivating historical literacy among students, and the importance of encouraging them to create their own images of the past (Lee, 2005a; Howson, 2007, 2009; Shemilt, 2000; Howson and Shemilt, 2011). In particular, researchers have sought ways in which students can create coherent images of the past ('big pictures') that will simultaneously support temporal orientation, the development of historical thinking and the formulation of different views (Ashby and Edwards, 2010; Lee, 2011; Shemilt, 2011). Examining thematic topics over long periods of time, along with an in-depth study of events and short periods of time, allows students to develop an understanding of historical contexts with consistency. Among the proposed teaching pack titles focusing on prehistory are: 'Hunters, farmers, sailors and craftsmen in the prehistoric Aegean'; 'From the Petralona cave to the Mycenaean palace' (fourth-grade primary school); 'The Palaeolithic man conquers the world'; and 'Is there space for everyone? Contacts and rivalries between two palatial societies' (first-grade secondary school).

Therefore, through the expansion of cognitively focused content and the application of teaching methods that encourage a deeper understanding of the issues, students are better able to use the conceptual tools of historical thinking and are guided towards a deeper understanding of prehistory and the development of metacognitive skills for the following study periods.

The second notable element of the new curriculum is the use of archaeology, museums and material culture as structural tools for researching and understanding not only prehistory, but also ancient history. The curriculum at both primary and secondary levels includes special sections on the methods and tools of archaeology and history. For example, in the syllabus of the fourth grade of primary education, approximately seven hours are devoted exclusively to the introduction and elaboration of concepts used within the discipline of archaeology. Integrating the methodology of the science of archaeology with the teaching of history is a major innovation in Greek education. Emphasis is placed on understanding how archaeological and then historical knowledge is produced. The aims and methods of archaeology, as well as the stages of research, are connected to second-order concepts such as time, types of archaeological sources (artefacts, architectural structures and organic remains), and continuity and change in space and time. The teaching suggestions associated with the science of archaeology have an experiential character, and include simulated excavations and the study of replica finds as well as contemporary objects. Through deduction and comparison with artefacts, places and practices, students are better able to understand and to make connections between the past and the present. This will enable them to develop their research skills through observation, description, and comparison and interpretation of objects, as well as to appreciate how decisions were made in the past and how individuals functioned as agents in the creation of the archaeological record (AriasFerrer and Egea-Vivancos, 2017; Levstik et al., 2005; Levstik et al., 2014).

Historical thinking is inextricably linked to the utilization of material remains as sources of evidence, and with their interpretation as testimonies of the past. The reading of these objects as historical evidence is a difficult multilevel process, but it is an important skill that should be cultivated from an early age. The development of analytical skills focusing on the study of material remains, along with the teaching of students of all ages to distinguish, compare and explore the differences and varying 
perspectives of the range of subjects under study, gives a dynamic character to the educational use of material culture in the new history curriculum. Students are guided in the process of interpreting the past through their own historical investigation, using material remains as evidence. Archaeological sources of evidence for prehistory are unique, but they are also key to our understanding of all chronological periods. For this reason, the new history curriculum places particular emphasis on the use of material remains as historical sources for all periods. Contemporary trends in the field of historical education emphasize the different narratives that can be constructed by students based on the use of historical sources as testimonies (Lee, 2011).

Surveys involving Greek students have suggested that they believe that the past extends behind them as a compact and self-contained landscape (Apostolidou, 2006). They do not consider that there can be many different narratives about the past. According to Shemilt (2011), these alternative narratives are what constitute historical thinking. The alternative interpretations of the past in relation to the study of material remains in a museum context constitute views that are at the heart of historical thinking (Nakou, 2000). Many researchers in the field of historical education claim that archaeological finds and the material remains of the past are more than just another form of evidence, since they are particularly open to different interpretations (Kriekouki-Nakou, 1996). They argue that for students, they act as tangible evidence of life in the past, and so constitute a living history (Jones, 2011), offering them the opportunity to better understand concepts such as historical perspective, historical context and their own place in historical space and time (Kouseri, 2015). Others argue that this is because the material of the past is linked to the daily lives of students in the present, and for this reason allows them to compare and identify continuities and changes between the present and the past more easily, and to appreciate the material manifestations of human behaviour (Henderson and Levstik, 2016).

For this reason, the implementation of task-based research and exploration in museums, at archaeological sites and in other historical settings is included in the main body of indicative activities proposed for the teacher. These activities are also subsumed by the field of museum education, which is used as an integral part of the teaching process. Linking classroom-based teaching with more informal education, such as school visits to historical places, archaeological sites and museums, has in recent decades come to be viewed as vital for historical education in Greece (Nakou, 2009), as well as internationally (Falk et al., 2006; Marcus and Levine, 2011; Marcus et al., 2012). Museums are considered as privileged areas for history teaching, as they encompass a social, cultural and wider educational area in which students can interact with material from the past (Hooper-Greenhill, 2007). In the new Greek history curriculum, museumbased educational material is suggested, either for use before or after a study visit to a museum or in the creation of teaching practices that relate material culture with specific conceptual tools. Museums are not viewed as static institutions, since visits are not restricted to ineffectual and exhaustive guided tours, but rather as a means for posing questions both to and from the two educational institutions, the school and the museum, as well as for the further exploration of the fundamental concepts of history education. Proposals for creative visits to archaeological sites are also considered as being of crucial importance for the historical exploration of the past. Principles governing the argument for linking history education to museums are related to experiential and constructive learning, and the incorporation of up-to-date knowledge about the teaching process - approaches that have been at the heart of museum education for years (Hein, 1998; Hooper-Greenhill, 1994). In addition to museums, archaeological sites, excavations and other historical environments, including battlefields, castles 
and historic buildings, are fundamental for the development of historical thinking. They provide opportunities for experiential learning, historical enquiry and alternative interpretations, which illuminate aspects of local and general history (Corbishley, 2011; Henson et al., 2004).

Visits to museums and archaeological sites, and the study of material remains, allow for different readings and interpretation paths for students. These could include the composition of a storyboard of different experiences, or the selection of items of material and their inclusion in specific categories in order to create an exhibition at school. The creation of thematic reports in a classroom environment by groups of students, and the active support of their choices through the expression of interpretative reasoning, is an exercise that cultivates critical ways of viewing and reading corresponding reports of the past negotiated by various cultural institutions in the public sphere. The importance of these exercises reflects corresponding concerns that govern the field of museum education, which raise related questions of alternative interpretations, mainly through thematic reports.

Finally, a number of changes and revisions concerning the historiographic perspective of the subject matter itself are introduced. Without challenging the conventional and widely accepted linear periodization of Greek antiquity, a combination of chronological and thematic approaches is adopted, mostly for the first-grade lower secondary curriculum. In this respect, all the aforementioned innovations included in the new history curriculum are marked by a shift towards social and cultural history, and the critical rapprochement of the prevalent historiographic approaches to the ancient world (Fragkoudaki, 1997; Hamilakis, 2003; Kasvikis, 2004). In particular, both the content of the main textbook and the proposed thematic teaching packs highlight the political, social and ideological controversies and competing pursuits of the Greek city states that undermine the idyllic image of homogeneity and consensus in Greek antiquity. Class and gender discrimination are discussed, and war crimes are reevaluated in context and from their human perspective, while priority is given to issues of economy, ideology, culture and everyday life in the ancient world.

Moreover, both in the content knowledge and mainly in the activities proposed, emphasis is not placed solely on important historical events and figures, but on their impact and significance for the cultural dimension of human life in their time, as well as in the students' present. For example, Alexander the Great is not portrayed as a historical personality who defined people's lives as a conqueror. Instead, emphasis is placed on the impact of historical events revolving around him and how these affected people's everyday lives, the institutions, and the values of the historical context in which they lived. Emphasis on the important social and cultural changes that have taken place over the centuries and, to a lesser extent, on the examination of specific persons or events, enables students to explore the past using research tools based on scientific approaches, and particularly their understanding of the concepts of change and continuity over time. This helps them to overcome stereotypical perceptions that are expressed in collective memory, to deal with conflicting views, to perceive - through appropriate teaching strategies - the multiple dimensions of a historical phenomenon and, above all, to recognize the moral aspect of the actions of the past for their lives in the present. For this endeavour, both the aims and the activities recommended to teachers facilitate the building of evidence-based interpretations by students, examining a variety of historical sources and teaching materials (primary and secondary sources (either conflicting or not), material culture, images, timelines, maps, films, documentaries, websites, worksheets) and participating in tasks that employ empathy, enquiry, historical reasoning, role play, debates, drama, digital applications 
and created material, for appreciating issues of significance, agency, causality, multiperspectivity and morality dealing with the ancient past.

\section{Concluding remarks}

The new Greek history curriculum for compulsory education is closely linked to the scientific training of teachers in the context of the new results of historical and educational research. In addition, teachers will play a significant role in the construction of knowledge within a framework of history. They are called upon to make appropriate choices in different contexts, shaping learning environments for all their students, and encouraging free expression, dialogue and positive debate based on documentation, accuracy, accountability and synthesis.

In designing the new ancient Greek history module for the compulsory history curriculum, we were fully aware of the challenges and constraints imposed by the fact that in Greek collective memory, Classical antiquity has been elevated to the status of national property. Equally imposing barriers are also erected by the existence of a conservative historical culture shared by teachers and large parts of Greek society, which occasionally expresses passionate reactions against any progress in history education that would challenge the ethnocentric canon in terms of subject matter, and the informational character of history in terms of methodology. The rationale behind the curriculum is to provide a meaningful framework to improve the teaching of antiquity by reconsidering historical content, approaches and teaching strategies, and to promote the current educational rationale concerning the teaching and learning of history, aimed towards the development of historical thinking and consciousness.

The history curriculum for compulsory education was finalized in March 2018, and it has now been instituted throughout the country. It is expected that new textbooks will be written, and teachers trained. Moreover, it is hoped that in the near future, a national quantitative survey - as well as a more local qualitative study - of how teachers have received the changes to the history curriculum can be undertaken, providing useful feedback about the changes made and the best way forward.

We acknowledge that the innovative features discussed in this paper are sine qua non, and they represent opportunities and preconditions for a further emancipation of Greek history education from ideology and the uses and abuses of antiquity, leading towards a more sophisticated and pluralistic understanding of the 'miracle that was Greece'.

\section{Notes on the contributors}

Kostas Kasvikis is an assistant professor in history and culture didactics in the Department of Primary Education, University of Western Macedonia, Greece. He is also coordinator of the module Museum Education of the Interuniversity Postgraduate Programme in Museology-Cultural Management, Aristotle University of Thessaloniki and University of Western Macedonia. His areas of research include history didactics, museum education, textbooks research, public archaeology and the politics of the past.

Georgia Kouseri has worked as a secondary school teacher in Greece since 2001. She completed both her BA in history and archaeology (1992) and her MA in prehistoric archaeology (1998) at the Aristotle University of Thessaloniki. She also studied art conservation at the Technological Institute of Athens. In 2015, she was awarded a $\mathrm{PhD}$ by the University of Thessaly for her research entitled 'Historical Education in the 
School and in the Museum'. Her research interests include history didactics and the use of the past in formal and informal educational venues.

\section{References}

Apostolidou, E. (2006) 'The Historical Consciousness of 15-year-old Students in Greece'. Unpublished PhD thesis, Institute of Education, University of London.

Arias-Ferrer, L. and Egea-Vivancos, A. (2017) 'Thinking like an archaeologist: Raising awareness of cultural heritage through the use of archaeology and artefacts in education'. Public Archaeology, 16 (2), 90-109.

Ashby, R. and Edwards, C. (2010) 'Challenges facing the disciplinary tradition: Reflections on the history curriculum in England'. In Nakou, I. and Barca, I. (eds) Contemporary Public Debates over History Education. Charlotte, NC: Information Age Publishing, 27-46.

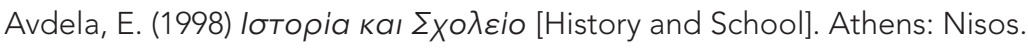

Avdela, E. (2000) 'The teaching of history in Greece'. Journal of Modern Greek Studies, 18 (2), 239-53.

Barton, K.C. and Levstik, L.S. (2004) Teaching History for the Common Good. Mahwah, NJ: Lawrence Erlbaum Associates.

Burn, K. (2015) 'The Gove legacy in the curriculum: The case of history'. In Finn, M. (ed.) The Gove Legacy: Education in Britain after the Coalition. Basingstoke: Palgrave Macmillan, 47-62.

Burn, K. (2016) 'Sustaining the unresolving tensions within history education and teacher education'. In Counsell, C., Burn, K. and Chapman, A. (eds) MasterClass in History Education: Transforming teaching and learning. London: Bloomsbury Academic, 233-42.

Chapman, A. (2015) 'Developing historical and metahistorical thinking in history classrooms: Reflections on research and practice in England'. Diálogos, 19 (1), 29-55.

Chapman, A. (2017) 'Causal explanation'. In Davies, I. (ed.) Debates in History Teaching. 2nd ed. London: Routledge, 130-43.

Chapman, A., Burn, K. and Kitson, A. (2018) 'What is school history for? British student-teachers' perspectives'. Arbor: Ciencia, Pensamiento y Cultura, 194 (788), Article a443, 1-14.

Corbishley, M. (2011) Pinning Down the Past: Archaeology, heritage, and education today. Woodbridge: Boydell Press.

Damaskos, D. and Plantzos, D. (eds) (2008) A Singular Antiquity: Archaeology and Hellenic identity in twentieth-century Greece. Athens: Benaki Museum.

Danforth, L.M. (1995) The Macedonian Conflict: Ethnic nationalism in a transnational world. Princeton: Princeton University Press.

DfE (Department for Education) (2013) 'National curriculum in England: History programmes of study'. Online. www.gov.uk/government/publications/national-curriculum-in-england-historyprogrammes-of-study/national-curriculum-in-england-history-programmes-of-study (accessed 15 July 2019).

Falk, J.H., Dierking, L.D. and Adams, M. (2006) 'Living in a learning society: Museums and freechoice learning'. In Macdonald, S. (ed.) A Companion to Museum Studies. Malden, MA: Blackwell Publishing, 323-39.

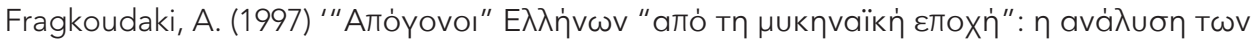

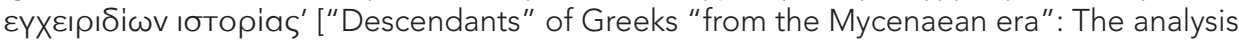

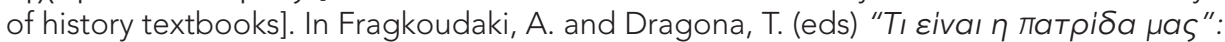

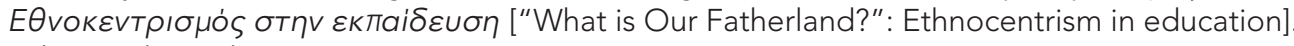
Athens: Alexandreia, 344-400.

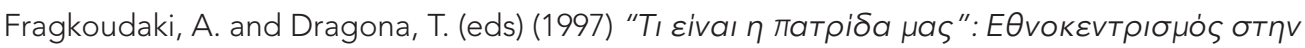
$\varepsilon \kappa \pi a i \delta \varepsilon \cup \sigma \eta$ ["What is Our Fatherland?": Ethnocentrism in education]. Athens: Alexandreia.

Hamilakis, Y. (2003) '"Learn history!": Antiquity, national narrative, and history in Greek educational textbooks'. In Brown, K.S. and Hamilakis, Y. (eds) The Usable Past: Greek metahistories. Lanham, MD: Lexington Books, 39-67.

Hamilakis, Y. (2007) The Nation and Its Ruins: Antiquity, archaeology, and national imagination in Greece. Oxford: Oxford University Press.

Hein, G.E. (1998) Learning in the Museum. London: Routledge.

Henderson, A.G. and Levstik, L.S. (2016) 'Reading objects: Children interpreting material culture'. Advances in Archaeological Practice, 4 (4), 503-16.

Henson, D., Stone, P. and Corbishley, M. (eds) (2004) Education and the Historic Environment. London: Routledge. 
Herzfeld, M. (1982) Ours Once More: Folklore, ideology, and the making of modern Greece. Austin: University of Texas Press.

Hooper-Greenhill, E. (1994) Museum and Gallery Education. Leicester: Leicester University Press.

Hooper-Greenhill, E. (2007) Museums and Education: Purpose, pedagogy, performance. London: Routledge.

Howson, J. (2007) '"Is it the Tuarts and then the Studors or the other way round?": The importance of developing a usable big picture of the past'. Teaching History, 127, 40-7.

Howson, J. (2009) 'Potential and pitfalls in teaching "big pictures" of the past'. Teaching History, 136, 24-33.

Howson, J. and Shemilt, D. (2011) 'Frameworks of knowledge: Dilemmas and debates'. In Davies, I. (ed.) Debates in History Teaching. London: Routledge, 73-83.

Jones, C. (2011) 'An Illusion That Makes the Past Seem Real: The potential of living history for developing the historical consciousness of young people'. Unpublished PhD thesis, University of Leicester.

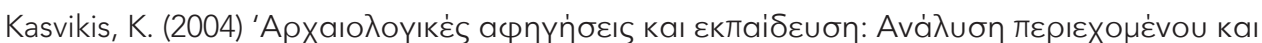

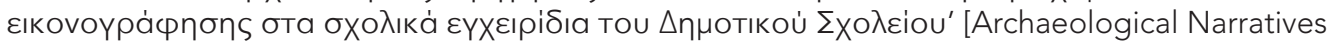
and Education: Content and illustration analysis of primary education textbooks]. Unpublished $\mathrm{PhD}$ thesis, Aristotle University of Thessaloniki.

Kasvikis, K. (2012) 'Prehistory in Greek primary education 1975-2012: Representations of a mythic and Hellenised past'. In Schücker, N. (ed.) Integrating Archaeology: Science, wish, reality. Frankfurt am Main: Römisch-Germanische Kommission, 121-6.

Kasvikis, K., Vella, N., Doughty, L., Borg, J. and Magro Conti, J. (2007) 'National curricula and the politics of archaeology'. In Hodder, I. and Doughty, L. (eds) Mediterranean Prehistoric Heritage: Training, education and management. Cambridge: McDonald Institute for Archaeological Research, 129-44.

Kokkinos, G., Athanasiadis, I., Vouri, S., Gatsotis, P., Trantas, P. and Stefos, E. (2005) loторıкń

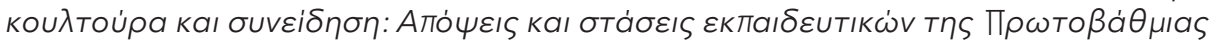

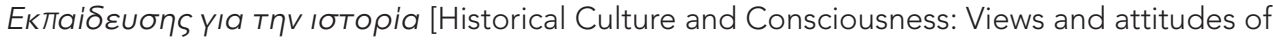
primary school teachers about history]. Athens: Noogramma.

Kotsakis, K. (1991) 'The powerful past: Theoretical trends in Greek archaeology'. In Hodder, I. (ed.) Archaeological Theory in Europe: The last three decades. London: Routledge, 65-90.

Kotsakis, K. (1998) 'The past is ours: Images of Greek Macedonia'. In Meskell, L. (ed.) Archaeology under Fire: Nationalism, politics and heritage in the Eastern Mediterranean and Middle East. London: Routledge, 44-67.

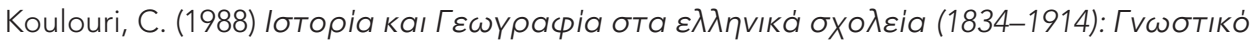

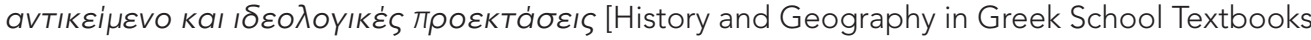
1834-1914: Learning subjects and ideological implications]. Athens: Istoriko Arxeio Ellinikis Neolaias 18, Geniki Grammateia Neas Genias.

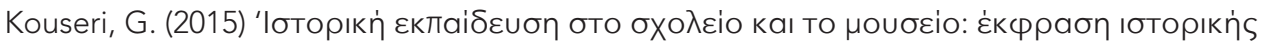

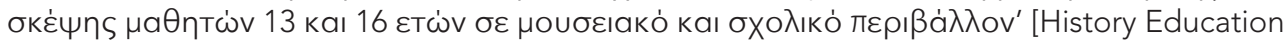
in the School and the Museum: Expression of historical thinking by 13 -year-old and 16-year-old students in museum and school environments]. Unpublished PhD thesis, University of Thessaly.

Kriekouki-Nakou, I. (1996) 'Pupils' Historical Thinking within a Museum Environment'. Unpublished PhD thesis, Institute of Education, University of London.

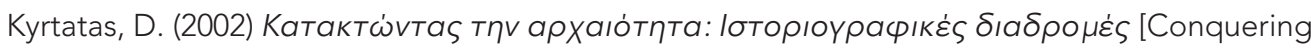
Antiquity: Historiographic paths]. Athens: Polis.

Lee, P. (2005a) 'Historical literacy: Theory and research'. International Journal of Historical Learning, Teaching and Research, 5 (1), 29-40.

Lee, P.J. (2005b) 'Putting principles into practice: Understanding history'. In Donovan, M.S. and Bransford, J.D. (eds) How Students Learn: History, mathematics, and science in the classroom. Washington, DC: National Academies Press, 31-77.

Lee, P. (2011) 'Historical literacy and transformative history'. In Perikleous, L. and Shemilt, D. (eds) The Future of the Past: Why history education matters. Nicosia: Association for Historical Dialogue and Research, 129-67.

Lee, P. and Ashby, R. (2000) 'Progression in historical understanding among students ages 7-14'. In Stearns, P.N., Seixas, P. and Wineburg, S. (eds) Knowing, Teaching, and Learning History: National and international perspectives. New York: New York University Press, 199-222.

Lévesque, S. (2008) Thinking Historically: Educating students for the twenty-first century. Toronto: University of Toronto Press.

Levstik, L.S., Henderson, A.G. and Lee, Y. (2014) 'The beauty of other lives: Material culture as evidence of human ingenuity and agency'. The Social Studies, 105 (4), 184-92. 
Levstik, L.S., Henderson, A.G. and Schlarb, J.S. (2005) 'Digging for clues: An archaeological exploration of historical cognition'. In Ashby, R., Gordon, P. and Lee, P. (eds) Understanding History: Recent research in history education (International Review of History Education 4). London: RoutledgeFalmer, 34-48.

Liakos, A. (2001) 'The construction of national time: The making of the modern Greek historical imagination'. Mediterranean Historical Review, 16 (1), $27-42$.

Marcus, A.S. and Levine, T.H. (2011) 'Knight at the museum: Learning history with museums'. The Social Studies, 102 (3), 104-9.

Marcus, A.S., Stoddard, J.D. and Woodward, W.W. (2012) Teaching History with Museums: Strategies for K-12 social studies. New York: Routledge.

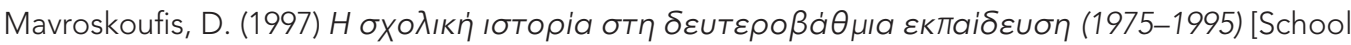
History in Secondary Education (1975-1995)]. Thessaloniki: Afoi Kyrakidi.

Ministry of Education - Pedagogical Institute (2003) $\triangle \imath$

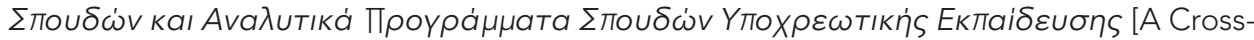
Thematic Curriculum Framework for Compulsory Education]. Athens.

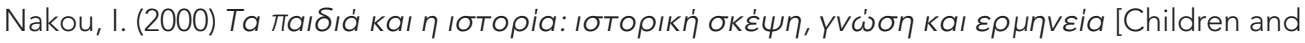
History: Historical thinking, knowledge and interpretation]. Athens: Metaichmio.

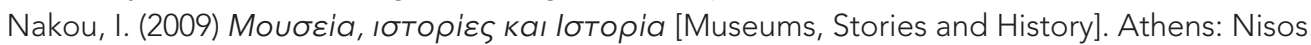

Papakosta, K. (2017) 'Teaching ancient Greek history in Greek compulsory education: Textual and ideological continuities and discontinuities'. Paedagogica Historica: International Journal of the History of Education, 53 (4), 477-89.

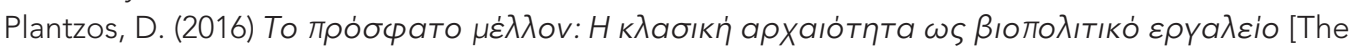
Recent Future: Classical antiquity as a biopolitics tool]. Athens: Polis.

Repoussi, M. (2011) 'History education in Greece'. In Erdmann, E. and Hasberg, W. (eds) Facing, Mapping, Bridging Diversity: Foundation of a European discourse on history education. Schwalbach am Taunus: Wochenschau Verlag, 329-70.

Rüsen, J. (2004) 'Historical consciousness: Narrative structure, moral function, and ontogenetic development'. In Seixas, P. (ed.) Theorizing Historical Consciousness. Toronto: University of Toronto Press, 63-85.

Seixas, P. (2010) 'A modest proposal for change in Canadian history education'. In Nakou, I. and Barca, I. (eds) Contemporary Public Debates over History Education. Charlotte, NC: Information Age Publishing, 11-26.

Seixas, P. and Morton, T. (2013) The Big Six Historical Thinking Concepts. Toronto: Nelson Education.

Shemilt, D. (2000) 'The caliph's coin: The currency of narrative frameworks in history teaching'. In Stearns, P.N., Seixas, P. and Wineburg, S. (eds) Knowing, Teaching, and Learning History: National and international perspectives. New York: New York University Press, 83-101.

Shemilt, D. (2011) 'The gods of the copybook headings: Why don't we learn from the past?'. In Perikleous, L. and Shemilt, D. (eds) The Future of the Past: Why history education matters. Nicosia: Association for Historical Dialogue and Research, 69-127.

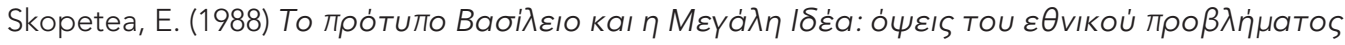

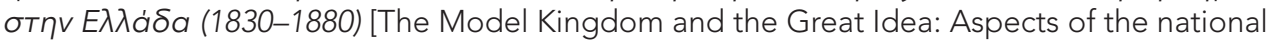
problem in Greece (1830-1880)]. Athens: Polytypo.

Stone, P. and MacKenzie, R. (eds) (1990) The Excluded Past: Archaeology in education. London: Unwin Hyman.

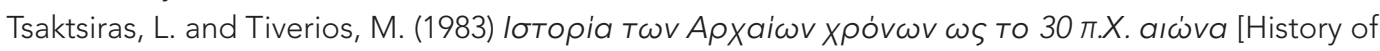
Ancient Times till 30 BC]. Athens: OEDB.

Tziovas, D. (ed.) (2014a) Re-imagining the Past: Antiquity and modern Greek culture. Oxford: Oxford University Press.

Tziovas, D. (2014b) 'Introduction: Decolonizing antiquity, heritage politics, and performing the past'. In Tziovas, D. (ed.) Re-imagining the Past: Antiquity and modern Greek culture. Oxford: Oxford University Press, 1-26.

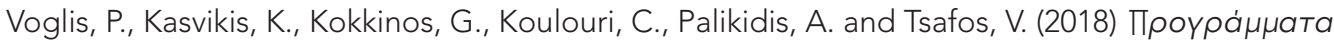

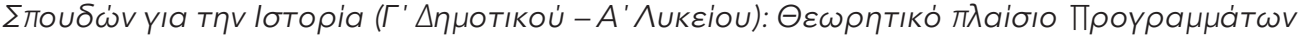

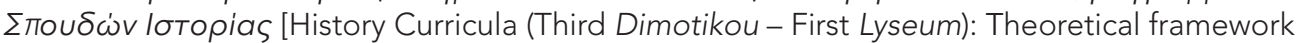
of the history curriculum]. Online. http://iep.edu.gr/images/IEP/EPISTIMONIKI_YPIRESIA/ Epist_Monades/B_Kyklos/Humanities/2018/2018-11-02_ps_istorias_eisagogi.pdf (accessed 22 July 2019).

Yalouri, E. (2001) The Acropolis: Global fame, local claim. Oxford: Berg. 